Q norden

\title{
LIGESTILLINGSVURDERING I KOMMUNALE MYNDIGHEDERS ARBEJDE
}

- Resultater og anbefalinger fra en tværnordisk kortlægning

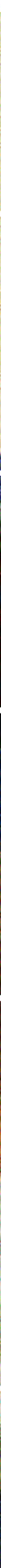


Ligestillingsvurdering i kommunale myndigheders arbejde

- Resultater og anbefalinger fra en tværnordisk kortlægning

ISBN 978-92-893-4091-5 (PRINT)

ISBN 978-92-893-4092-2 (PDF)

http://dx.doi.org/10.6027/ANP2015-745

ANP 2015:745

(c) Nordisk Ministerråd 2015

Layout: Gitte Wejnold

Omslagsfoto: SignElements.com

Foto: SignElements.com

Skrift: Meta LF

www.norden.org/da/publikationer

\section{Det nordiske samarbejde}

Det nordiske samarbejde er en af verdens mest omfattende regionale samarbejdsformer. Samarbejdet omfatter Danmark, Finland, Island, Norge og Sverige samt Færøerne, Grønland og Åland.

Det nordiske samarbejde er både politisk, økonomisk og kulturelt forankret, og er en vigtig medspiller i det europæiske og internationale samarbejde. Det nordiske fællesskab arbejder for et stærkt Norden i et stærkt Europa.

Det nordiske samarbejde ønsker at styrke nordiske og regionale interesser og værdier i en global omverden. Fælles værdier landene imellem er med til at styrke Nordens position som en af verdens mest innovative og konkurrencedygtige regioner.

\section{Nordisk Ministerråd}

Ved Stranden 18

DK-1061 Copenhagen K

Telefon (+45) 33960200

www.norden.org 


\section{LIGESTILLINGSVURDERING I KOMMUNALE MYNDIGHEDERS ARBEJDE}

- Resultater og anbefalinger fra en tværnordisk kortlægning 


\section{INDHOLD}

Ligestilling i en tværnordisk kontekst $\quad 6$

Udbytte af at foretage ligestillingsvurderinger $\quad 8$

Anbefalinger til arbejdet med ligestillingsvurdering 11

1.1.1 Helhedsorienteret versus problemorienteret tilgang 12

1.1.2 Politisk initieret/ ledelsesinitieret versus ildsjæle $\quad 14$

$\begin{array}{lll}\text { 1.1.3 Italesættelse og legitimitet } & 18\end{array}$

1.1.4 Fokus på kønsligestilling versus fokus på mangfoldighed 20

1.1.5 Ressourcer og procedurer/redskaber 22

$\begin{array}{lll}\text { 1.1.6 Dokumentation } & 24\end{array}$

$\begin{array}{ll}\text { Yderligere viden } & 26\end{array}$ 


\section{LIGESTILLING I EN TVAERNORDISK KONTEKST}

\section{HVAD ER LIGESTILLINGSVURDERING?}

Begrebet ligestillingsvurdering dækker over en metode, som handler om at indarbejde et køns- og ligestillingsperspektiv i offentlig forvaltning og planlægning, hvor køn kan have en betydning. Det handler om, at politiske beslutninger og kerneydelser udarbejdes på baggrund af et oplyst grundlag og på baggrund af en bevidsthed om, at køn er en faktor, der har betydning for alle politikområder.

Når ligestilling indarbejdes i lovgivning og aktiviteter, fokuseres der på, hvorvidt de forskelle, der kan være mellem køn på et givent fagområde, giver anledning til særlige indsatser eller til, at indsatser skal udformes anderledes for at nå den relevante målgruppe. Det vil ofte være nødvendigt at koble køn med andre parametre fx uddannelse, civilstand, etnicitet, alder mv. for at få et tilstrækkeligt præcist billede af målgruppen og dermed grundlag for at målrette indsatsen mv.

Begrebet ligestillingsvurdering bruges i Danmark. I de andre nordiske lande benyttes begreberne "Integrering av könsperspektiv/Jämstallhetsintegrering" (FI), "Kynjasampætting/kønsintegrering" (IS), "Sektoransvar for integrering av kjønnslikestilling "(NO) og "lämstallhetsintegrering" (SE).
DE NORDISKE LANDE er generelt karakteriseret ved et omfattende fokus på kønsligestilling og har historisk haft en høj grad af ligestilling mellem kvinder og mænd og piger og drenge sammenlignet med andre lande. Dette gør sig gældende i uddannelsessystemet, på arbejdsmarkedet, i det politiske system og i samfundet generelt. Dette afspejles ligeledes ved, at de nordiske lande ligger højt på the 'Global Gender Gap Index', hvor Island bl.a. har ligget nummer ét fem år i træk ${ }^{1}$. Til trods for de nordiske landes høje rangeringer i internationale sammenligninger vedrørende ligestilling mellem kønnene, er det forsat vigtigt at have fokus på at styrke arbejdet med ligestilling/ligestillingsvurdering, da kvinder og mænd har forskellige behov og adfærd, som kan påvirke deres muligheder for at udnytte deres ressourcer fuldt ud i samfundet og deres hverdag.

Denne pjece sætter fokus på resultaterne af en kortlægning af ligestillingsvurderinger af kerneydelser på kommunalt niveau i de nordiske lande. Kortlægningen blev iværksat af det danske ministerium for Børn, Ligestilling, Integration og Sociale Forhold for at få viden om, hvordan de offentlige myndigheder i praksis benytter ligestillingsvurderinger i forhold til politikområder og kerneydelser. Kortlægningen er økonomisk støttet af Nordisk Ministerråd. Kortlægningen er gennemført af Oxford Research.

Kortlægningen er baseret på studier af 21 good practice eksempler for 


\section{KERNEYDELSER/VELFARDSTJENESTER/CORE SERVICES I DEN OFFENTLIGE SEKTOR}

Begrebet kerneydelser refererer til de tilbud, offentlige myndigheder stiller til rådighed for borgerne. Tilbuddene, der også kan kaldes velfærdstjenester eller borgerrettede serviceydelser, dækker primært over fagspecifikke opgaver i den offentlige sektor, eksempelvis:

- Forebyggende sundhedsindsatser

- Anlæg og vedligehold af cykelstier

- Tildeling af kulturtilskud

- Drift af plejehjem

- Pasningstilbud til børnefamilier

- Offentlig transport og vedligehold af veje

- Beskæftigelsesindsats

- Undervisningstilbud

På engelsk oversættes begrebet kerneydelser i den offentlige sektor til core services in the public sector.

ligestillingsvurdering af kommunernes kerneydelser ${ }^{2}$. Fokus er særligt på, hvordan køn og ligestilling kan tænkes ind i de borgerrettede ydelser ved brug af ligestillingsvurdering som metode, samt hvilke resultater og effekter dette kan medføre.

På denne baggrund gives der anbefalinger og inspiration til, hvordan offentlige myndigheder bedst kan arbejde med ligestillingsvurderinger. Formålet er at inspirere beslutningstagere såvel som praktikere til at øge fokus på ligestilling og ligestillingsvurdering af de borgernære kerneydelser og borgerettede indsatser.

Pjecen indeholder først en beskrivelse af, hvad der ligger i begrebet ligestillingsvurdering ${ }^{3}$.Dernæst beskrives de overordnede resultater og effekter af kortlægningen, og endelig gives der eksempler på arbejdet med ligestillingsvurdering af kerneydelser samt anbefalinger til, hvordan dette arbejde kan gribes an.
${ }^{1}$ The World Economic Forum, 2013, The Global Gender Gap Report 2013

${ }^{2}$ Ser mere under afsnittet: Yderligere viden, bagsiden ${ }^{3}$ De nordiske landes definitioner af ligestillingsvurdering bygger alle på Europarådets definition, se: http://www.coe. int/t/dghl/standardsetting/equality/03themes/gendermainstreaming/index_en.asp 


\section{UDBYTTE AF AT FORETAGE LIGESTILLINGSVURDERINGER}

Kortlægningen viser, at kommunerne opnår såvel resultater som effekter ved at gennemføre ligestillingsvurderinger. Kommunerne kan opnå resultater i form af øget kvalitet $i$ kerneydelsen, optimering af ressourcer samt holdnings- og adfærdsændringer. Kortlægningen viser endvidere, at disse resultater fører til øget ligestilling (effekt).

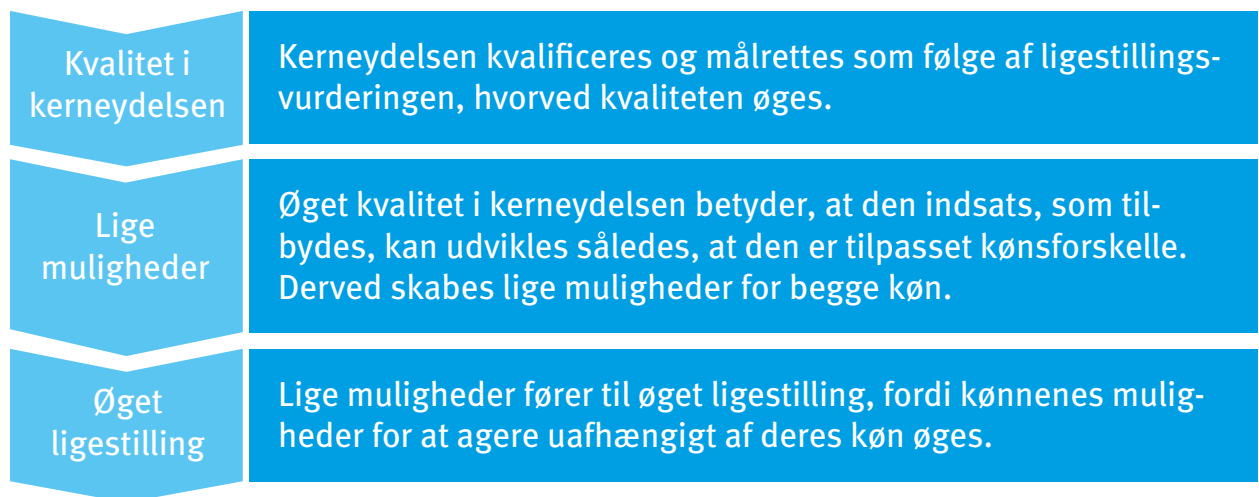

Kortlægningen viser, at ovenstående resultater og effekter kan skabes, hvis følgende er opfyldt:

- Der afsættes ressourcer til arbejdet med ligestillingsvurdering

- Der udvikles faste procedurer og redskaber til arbejdet med ligestillingsvurdering

- Der skabes legitimitet i forhold til køn og ligestilling bl.a. ved at italesætte ligestilling og $\mathrm{k} ø n$

- Ligestilling og køn italesættes for at skabe legitimitet samt bevidsthed om ligestilling og $k ø n$
- Et mangfoldighedsperspektiv inddrages, således at andre faktorer end køn ikke overses

- Der opstilles målsætninger og indikatorer for resultater og effekter i forhold til køn og ligestilling

- Resultater og effekter i forhold til ligestilling dokumenteres.

Kortlægningen viser, at der er en store forskelle i tilgangen til ligestillingsvurdering på tværs af de nordiske lande. Forskellene hænger i høj grad sammen med de nationale kontekster, herunder både politiske, økonomiske og kulturelle forhold, som påvirker, hvordan der arbejdes med ligestillingsvurderinger i de nordiske lande.

I Danmark arbejdes der primært ud fra en problemorienteret tilgang, hvilket vil sige, at der tages udgangspunkt $i$ en brændende platform - et konkret problem for en bestemt gruppe af borgere, der $\varsigma \varnothing$ ges løst. Det betyder, at indsatserne i Danmark er mere reaktive frem for forebyggende. 


\section{Øget ligestilling kræver både proaktive og reaktive indsatser}

I Sverige er indsatserne mere helhedsorienterede, og mange af indsatserne har karakter af at være forebyggende, idet der tænkes i holdnings- og adfærdsændringer. Ved at have fokus på holdnings- og adfærdsændringer skabes en mere langsigtet effekt.

I Norge er der helhedsorienterede programmer på udvalgte områder, mens der i Finland er helhedsorienterede programmer i udvalgte kommuner. På det overordnede niveau arbejdes der dog primært ud fra en problemorienteret tilgang $i$ både Finland og Norge.

Oxford Research vurderer, at den ene tilgang ikke nødvendigvis er 'bedre' end den anden. Det er muligt at skabe resultater og effekter via begge tilgange. Det væsentligste er, at der er bevidsthed om, om man arbejder problem - eller helhedsorienteret.

For at ændre uligheden mellem kønnene er det essentielt både at iværksætte proaktive og reaktive indsatser, idet forebyggelse kan ændre forholdene på længere sigt, og reaktive indsatser kan adressere de ulighedsproblematikker, der aktuelt eksisterer og således skabe resultater på kort sigt. 


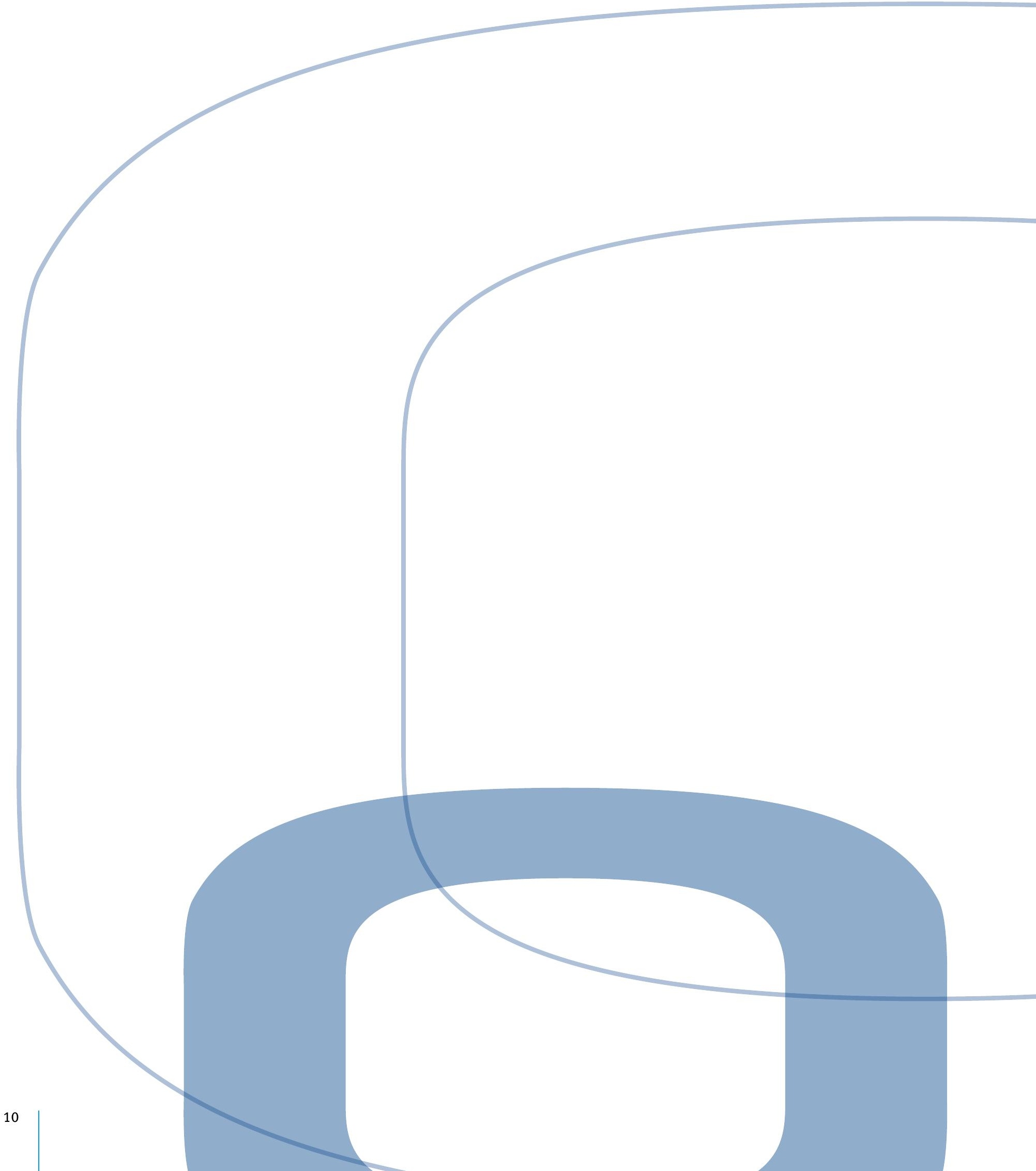




\section{ANBEFALINGER TIL ARBEJDET MED LIGESTILLINGSVURDERING}

I følgende afsnit præsenteres anbefalinger og konkrete eksempler på arbejdet med ligestillingsvurderinger. De konkrete eksempler er good practice eksempler på, hvordan forskellige offentlige myndigheder gennemfører ligestillingsvurderinger.

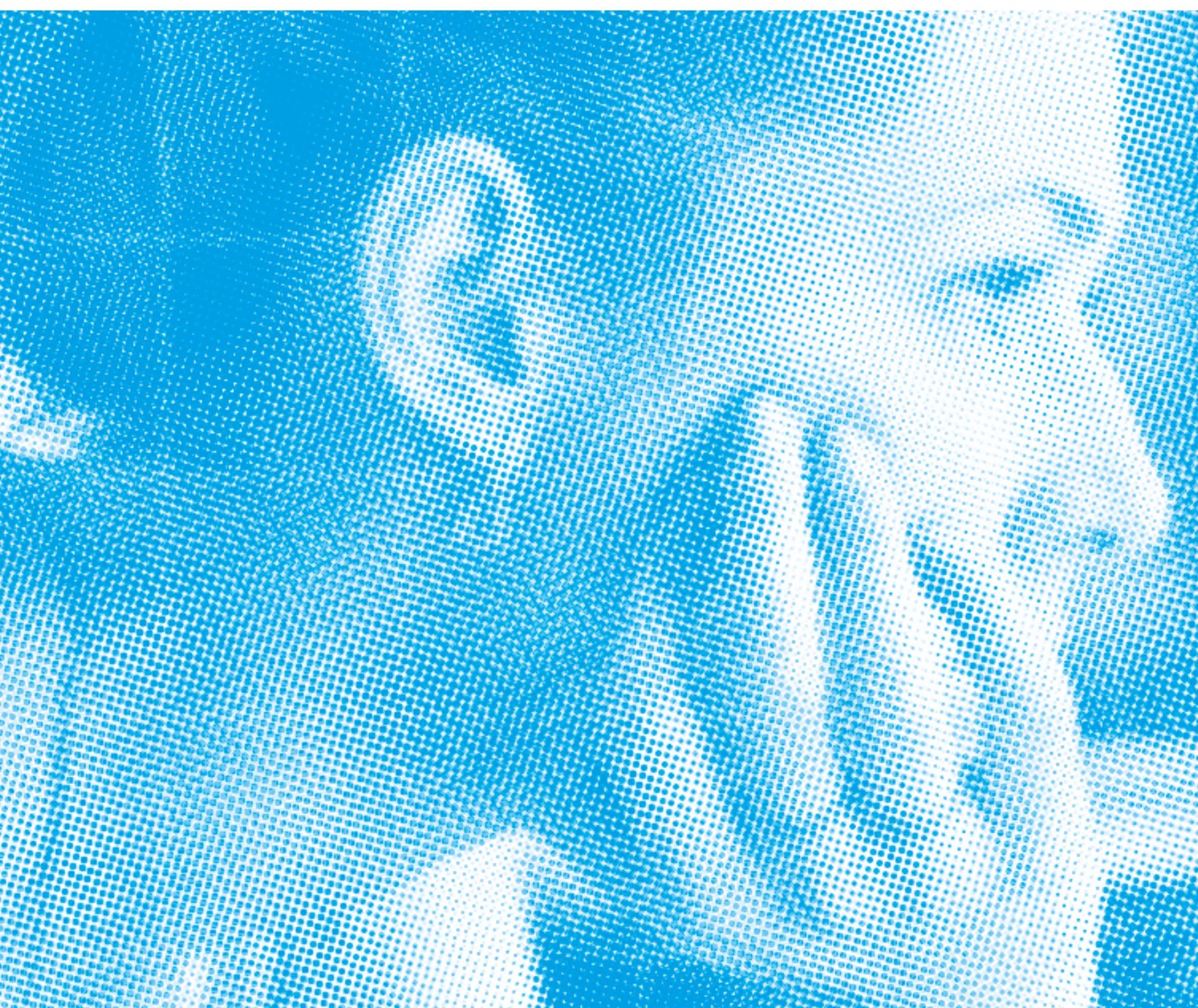




\subsection{1}

\section{HELHEDSORIENTERET VERSUS PROBLEMORIENTERET TILGANG}

Ved at tænke problemorienteret skabes målrettede indsatser; herved adresseres konkrete problemstillinger for specifikke grupper af borgere. Denne tilgang kan bidrage til at hjælpe den pågældende gruppe af borgere ved $\mathrm{fx}$ at give dem flere muligheder og større handlerum. Dette resulterer $i$, at målgruppen bliver mere ligestillede med andre borgere.
Ved at have en mere helhedsorienteret tilgang skabes der i højere grad holdnings- og adfærdsændringer, som har et mere proaktivt fokus. Derved ændres indstillingen til ligestilling, og der skabes legitimitet om ligestilling, fordi der er politisk opbakning og fokus. At arbejde med en problemorienteret tilgang skaber således primært resultater på kort sigt, mens der i den helhedsorienterede tilgang er mere fokus på langsigtede effekter i forhold til ligestilling. De to tilgange er karakteriseret ved følgende elementer:

\section{Helhedsorienteret tilgang}

- Ligestillingsvurdering foregår på flere områder eller niveauer: På det overordnede politiske niveau og/eller på forvaltningsniveau

- Internt fokus på medarbejderne og et eksternt fokus på borgerne i ligestillingsarbejdet

- Et stærkt ledelsesfokus og en eksplicit og strategisk tilgang til ligestillingsvurdering

- Legitimitet og italesættelse af ligestilling

- Top-down tilgang, som er højt prioriteret $\mathrm{i}$ organisationen

- Afsættes af ressourcer og support til medarbejderne

- Tilgangen er præget af systematik

- Fokus på forankring af nye arbejdsgange, rutiner og redskaber

\section{Problemorienteret tilgang}

- Udgangspunktet er et konkret problem, der skal løses

- Målgruppeanalyse med køn som central faktor

- Ligestilling er ikke et mål i sig selv

- Alternativ italesættelse af ligestilling fx mangfoldighed

- Manglende legitimitet af ligestillingsperspektivet

- Ligestillingsvurdering er en pragmatisk tilgang

- Ligestillingsperspektivet initieres af ildsjæle

- Bottom-up tilgang til ligestillingsvurdering

- Ressourcer og support er begrænset eller ikke-eksisterende

- Indsatsen er projektbaseret

- Ikke fokus på forankring og dokumentation 


\section{Konkret i forhold til de to tilgange anbefales det:}

- at konteksten indtænkes, når indsatser igangsættes, fx i forhold til de tilgængelige ressourcer, og hvordan indsatsen skal italesættes for at motivere både medarbejdere og borgere.
- at der både iværksættes helhedsorienterede og problemorienterede indsatser, idet begge typer af indsatser, det vil sige proaktive og reaktive, er nødvendige for at øge ligestillingen mellem kønnene. I denne sammenhæng er det essentielt at være bevidst om, hvilken type indsats, der igang sættes, og hvilke resultater og effekter, der dermed realistisk kan forventes.
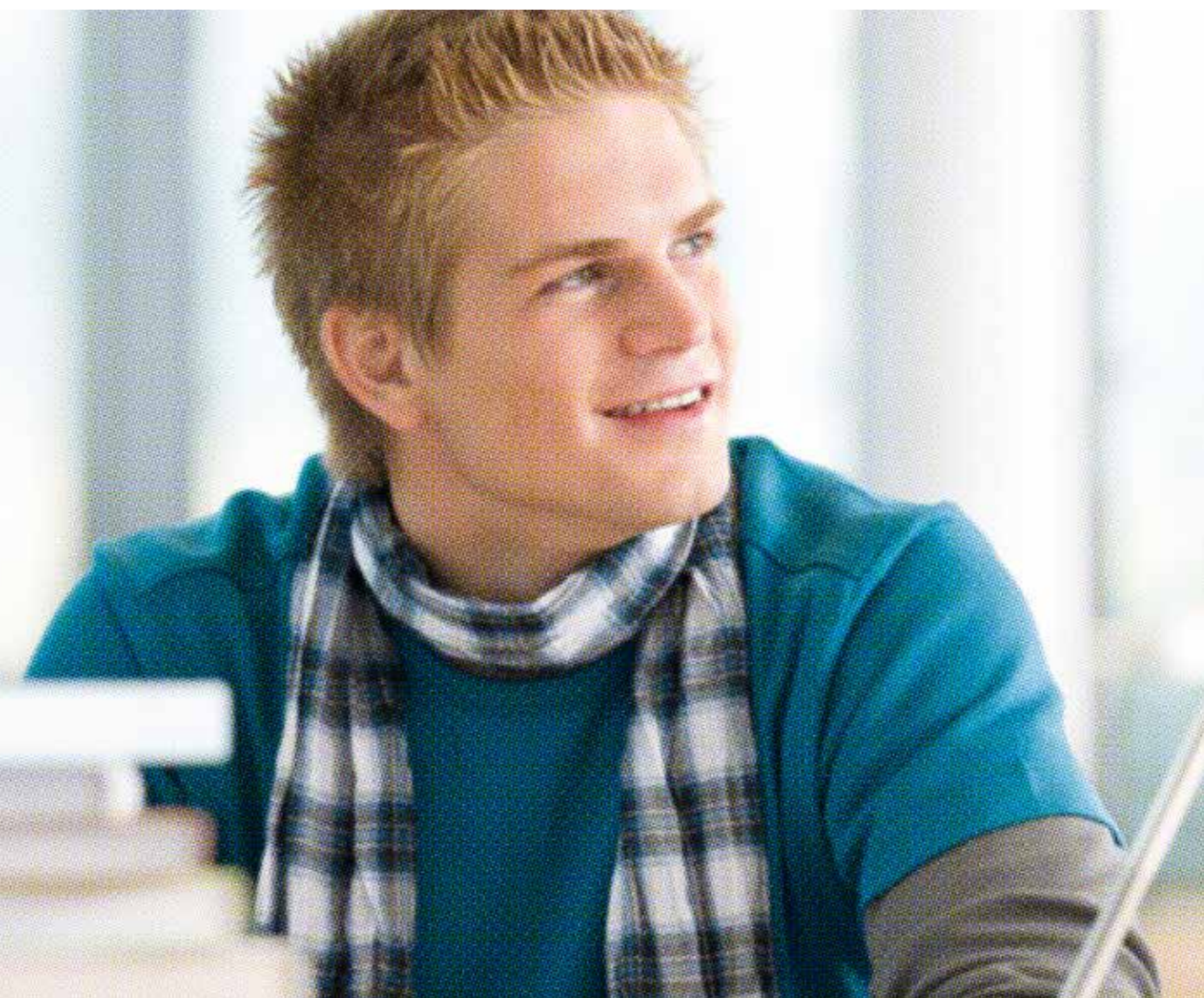


\subsection{2}

\section{POLITISK INITIERET/LEDELSES- INITIERET VERSUS ILDSJ/ELE}

En politisk, strategisk tilgang skaber legitimitet i forhold til indsatsen og brugen af ressourcer i forbindelse med indsatsen, fordi det er prioriteret og besluttet fra politisk hold.

Den ledelsesinitierede tilgang har den fordel, at der er ledelsesmæssig opbakning til det ligestillingsmæssige fokus i indsatsen eller det ligestillingsfremmende initiativ, hvilket gør det nemmere for medarbejderne at afsætte tid og ressourcer til indsatsen.

Tiltag initieret af ildsjæle bevirker, at medarbejderne og/eller ledere er engagerede og motiverede for ligestilling, men det gør også indsatsen sårbar, fordi den afhænger af få aktører.
Praksiseksemplerne nedenfor viser eksempler på en en indsats initieret af ildsjæle og en politisk/ledelsesinitieret indsats.

I forhold til indsatser, der er initieret fra henholdsvis politisk eller ledelsesmæssig hold eller af ildsjæle, anbefales det:

- at både medarbejdere og ledere involveres og engageres $i$ indsatsen for, at indsatsen er mindre sårbar for udskiftninger i medarbejder - og lederstaben.

- at både ledere og medarbejdere uddannes i at foretage kønsanalyser som første led $\mathrm{i}$ arbejdet med ligestillingsvurdering, da det kræver specifikke kvalifikationer at foretage kønsanalyser.
- at både ledere og medarbejdere uddannes i ligestilling og ligestillingsvurdering, idet det dels kræver specifikke kvalifikationer at foretage ligestillingsvurderinger, dels gør arbejdet med ligestillingsvurdering mere meningsfuldt for medarbejderen/lederen, hvis vedkommende har opnået en vis forståelse for ligestillingsområdet generelt.

- at uddannelse i kønsanalyser, ligestilling og ligestillingsvurdering varetages af aktører med kendskab til både ligestilling og kommunernes arbejde for på den måde at kunne sætte arbejdet med ligestilling ind i den kommunale kontekst. 


\section{PRAKSISEKSEMPEL - POLITISK/LEDELSES-INITIERET}

Vanda Stad i Finland har gennem de sidste 10 år arbejdet med ligestillingsområdet, og i 2009 besluttede Vanda Stad, at ligestillingsvurderinger skulle foretages på samtlige forvaltningsområder i kommunen. I den forbindelse blev der iværksat et projekt for at udvikle en model for kommunens ungeindsats over for ledige. Der blev igangsat et samarbejde mellem arbejdsformidlingen og Folkpensionsanstalt, som hurtigt kunne hjælpe de unge fra arbejdsløshed til beskæftigelse, praktik, uddannelse eller andre tiltag. Tiltaget er således et led $i$ et politisk initieret fokus, og der er allokeret økonomiske ressourcer samt medarbejderressourcer til indsatsen.

Et resultat af indsatsen er indarbejdelsen af et afsnit i medarbejdernes arbejdsbeskrivelse om indtænkning af $k ø n$ i forhold til vejledning af de unge samt konkrete redskaber til, hvordan der generelt kan integreres et kønsperspektiv i både projektog driftsopgaver. Der er i perioden 2010-2013 skabt 821 nye arbejdspladser og ydet rådgivning til 3.864 unge, som på grund af fokus på kønsaspektet har fået en højere grad af individuel og målrettet rådgivning. Denne tilgang har tillige bidraget til at øge de unges tillid til det offentlige system. Hertil kommer, at 244 unge har søgt videre uddannelse, og 213 virksomheder deltog i samarbejdet. 



\subsection{3}

\section{ITALESAETTELSE OG LEGITIMITET}

Kortlægningen viser, at det er væsentligt at diskutere køns-/ligestillingsperspektivet i de indsatser, der iværksættes. Ved løbende at diskutere køns-/ligestillingsperspektivet kvalificeres tilgangen i indsatsen i takt med, at indsatsen udvikler sig, og køns-/ligestillingsperspektivet fastholdes $\mathrm{i}$ indsatsen.

Kortlægningen viser, at der er forskel på, hvor legitimt det er at italesætte ligestilling i de forskellige nordiske lande, og det er vigtigt at være sig den specifikke konktekst bevidst og vurdere, i hvilken grad ligestilling skal italesættes i forhold til den konkrete indsats.

Kortlægningen viser imidlertid tillige, at en ekstern italesættelse af indsatsen som en ligestillings- indsats i de fleste tilfælde vurderes at kunne bidrage til at skabe mere bevidsthed om ligestilling hos borgerne. Kun i tilfælde, hvor det udelukker borgere fra at deltage i indsatsen, eller der er risiko for stigmatisering af bestemte grupper, bør ligestillingsperspektivet udelukkende italesættes internt i organisationen.

Praksiseksemplet nedenfor viser, hvordan italesættelse af ligestilling kan bidrage positivt til at skabe kvalitet i kerneydelsen.

I forhold til italesættelse af og legitimitet i forhold til ligestilling anbefales det:

- at det overvejes, om det er hensigtsmæssigt i forhold til den pågældende indsats at italesætte indsatsen som en ligestillingsindsats, da det kan skabe stigmatisering af og/eller afholde borgere fra at deltage $\mathrm{i}$ indsatsen.

- at køn italesættes direkte i de indsatser, hvor det er formålstjenligt, således at der skabes fokus på ligestilling i samfundet.

- at ligestilling og køn italesættes internt i organisationen for at kvalificere køns-/ligestillingsbegrebet, der arbejdes ud fra og for at skabe fokus på ligestilling og ligestillingsarbejdet. 


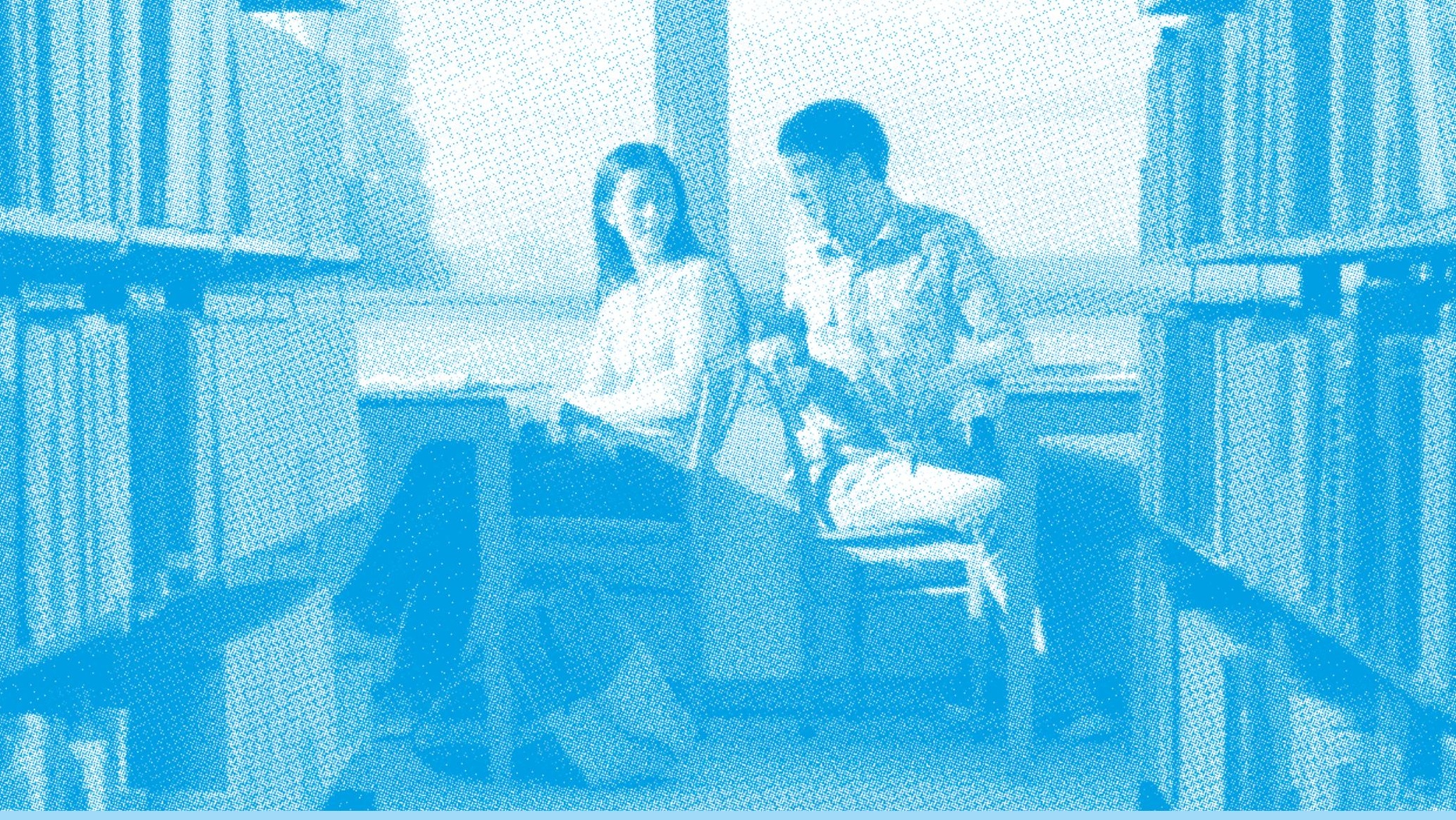

\section{PRAKSISEKSEMPEL - ITALESAETTELSE}

Högstadieskolan Bleketskolan i Tjörns Kommune i Sverige har inden for de seneste år arbejdet eksplicit med ligestilling. Pædagogerne på skolen drives af tanken om at forandre drenge og pigers vilkår og muligheder, således at de har de samme forudsætninger for at tage en uddannelse. På denne baggrund har skolen udarbejdet en handlingsplan for ligestillingsarbejdet indeholdende strategier, arbejdsmetoder og konkrete tiltag, der kan tages i brug. Formålet er dermed at øge ligestillingen og skabe lige muligheder. For at opnå dette har skolen som første stadie i indsatsen sendt udvalgte medarbejderne på uddannelse i ligestilling. Desuden har samtlige medarbejdere gennemført litteraturstudier af kønsteori for at skabe fokus på ligestilling og motivation for indsatsen. Ligeledes afholder medarbejderne løbende diskussionsgrupper for at diskutere de kønsrelaterede praksisser, og hvordan de eventuelt skal ændre deres adfærd ud fra dette. Eleverne er ligeledes direkte involveret i ligestillingsarbejdet, hvormed de får en klar forståelse af ligestilling.

Arbejdet har resulteret $\mathrm{i}$, at der er udviklet en metodehåndbog, der indeholder forslag til arbejdsmåder samt erfaringer og resultater, der kan medvirke til at forankre indsatsen, når lærere eller andre medarbejdere udskiftes. 


\subsection{4 \\ FOKUS PÅ KØNSLIGESTILLING VERSUS FOKUS PÅ MANGFOLDIGHED}

I ovenstående ses et eksempel på, hvordan det kan være fremmende for ligestillingsarbejdet samt gavnligt for kvaliteten i kerneydelsen at have et eksplicit fokus på og italesatte ligestilling.

For at skabe effekter i forhold til ligestilling, særligt i et bredere og mere langsigtet perspektiv, peger kortlægningen således på, at det er nødvendigt, at der arbejdes eksplicit med ligestilling, for at medarbejdere og ledelse bliver bevidste om uhensigtsmæssigheder i en given indsats.

Kortlægningen viser, at indsatser, der har fokus på mangfoldighed, ofte er baseret på målgruppeanalyser, hvor flere faktorer, herunder uddannelsesniveau, etnicitet, alder og køn, inddrages. Således er der fokus på flere faktorer end køn.

Når der i højere grad fokuseres på flere forskellige faktorer risikerer ligestillingsperspektivet at komme i baggrunden, da disse faktorer kommer i konkurrence. Det vil fx sige, at det har større betydning for udviklingen af indsatsen, at borgerne $\mathrm{fx}$ er lavtuddannede eller har en anden etnisk baggrund end dansk.

Nedenstående eksempel viser, at det i specifikke sammenhænge kan være relevant at omtale indsatsen som en mangfoldighedsindsats.

\section{I forhold til italesættelse af lige- stilling som kønsligestilling eller mangfoldighed anbefales det:}

- at køn indtænkes i alle indsatser, hvor køn er en faktor, der har betydning.

- at det sikres, at der foretages kvantitative og/eller kvalitative undersøgelser af, om et kønsperspektiv kan ændre uhensigtsmæssig adfærd, og at denne viden inddrages i udviklingen af indsatser.

- at andre ulighedsfaktorer, som fx uddannelsesniveau, etnicitet og alder, inddrages i kommunernes indsatser, således at det sikres, at der tages højde for samtlige relevante faktorer. 


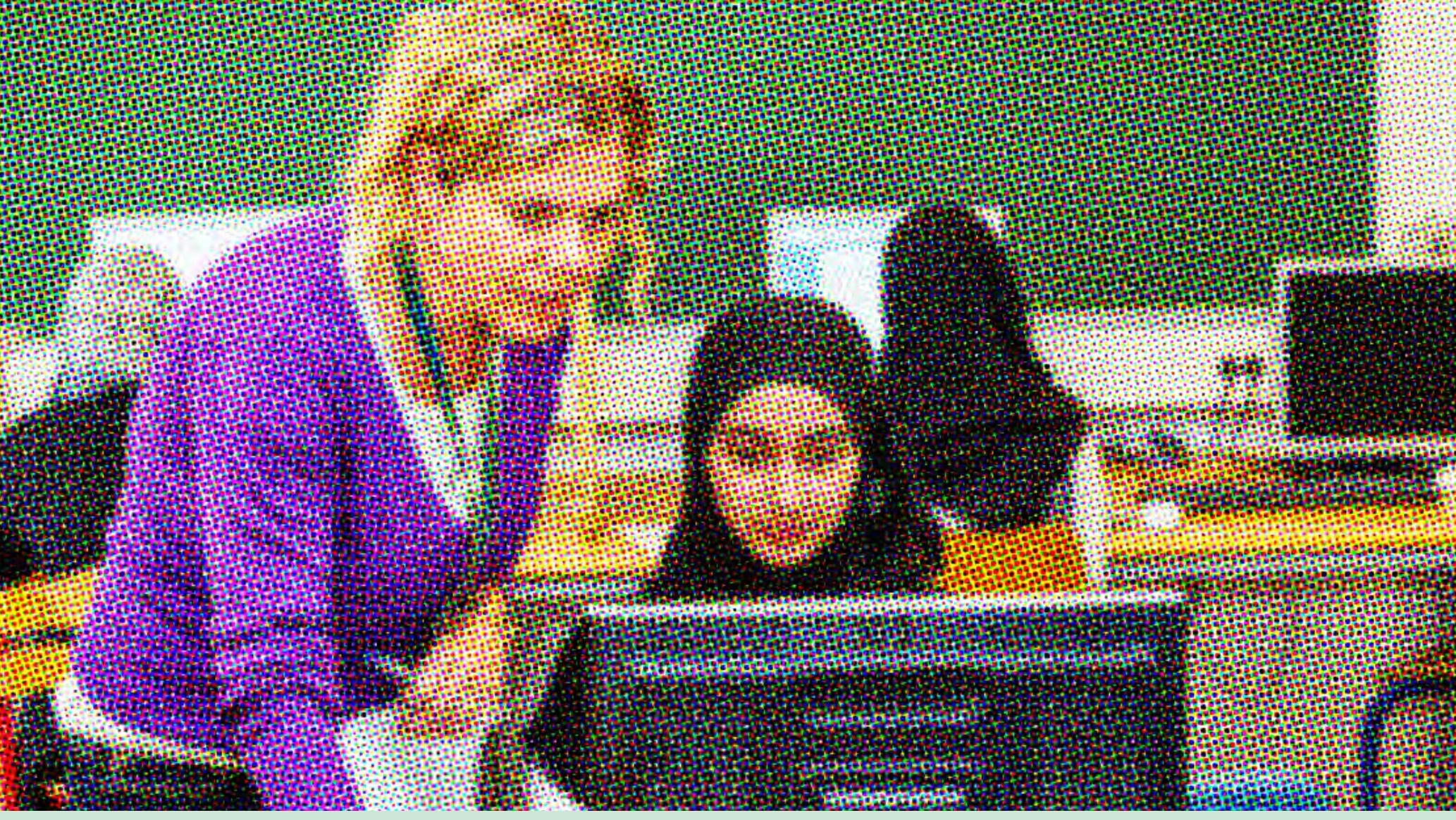

\section{PRAKSISEKSEMPEL - MANGFOLDIGHED}

Projekt MI-x i Aarhus Kommune i Danmark er et vejlednings- og afklaringsforløb for unge 18-29-årige kvinder med anden etnisk baggrund end dansk. Mlx står for mangfoldighed, integration og personlig X-faktor, og projektets formål er øget integration af unge, uddannelsessvage og udstødningstruede kvinder på det danske arbejdsmarked og i uddannelsessystemet.

Projektet er udviklet på baggrund af en målgruppeanalyse, hvor køn er en del af målgruppens karakteristika. Projektet indeholder tydelige ligestillingsmæssige aspekter både i selve organiseringen af indsatsen og $\mathrm{i}$ arbejdet med kvinderne, men projektet omtales ikke som et ligestillingsprojekt, hverken internt eller eksternt. Internt hænger det sammen med, at medarbejderne definerer projektet ud fra et mangfoldigheds- og 'lige muligheder for alle' perspektiv. Eksternt vil italesættelsen af ligestilling, ifølge medarbejderne, kunne hæmme målgruppens deltagelse i forløbet, da det potentielt vil skabe problemer $\mathrm{i}$ kvindernes bagland, som oftest i forvejen kan være en del af kvindernes udfordringer. Projektet har resulteret $\mathrm{i}$, at kvinderne er kommet et skridt tættere på selvforsørgelse, fordi kvinderne har øget deres personlige og faglige kompetencer og dermed er blevet bedre rustet i forhold til at tage uddannelse og indtræde på arbejdsmarkedet. Desuden har indsatsen betydet, at kvinderne har fået et nyt fællesskab med ligestillede og oplevet tryghed.

Good practice eksemplet peger således på, at det i nogle tilfælde kan være fremmende ikke at italesætte ligestillingsprojekter som ligestillende for på den måde at arbejde med emnet og på sigt opnå øget ligestilling over for bestemte målgrupper. 


\subsection{5 \\ RESSOURCER OG PROCEDURER/REDSKABER}

Kortlægningen viser, at allokering af ressourcer til arbejdet med ligestillingsvurdering øger kvaliteten i kerneydelserne.

Afsættelse af ressourcer er centralt for at skabe fokus på ligestilling og for at fastholde dette fokus. Det gælder i forhold til økonomiske midler, der er allokeret til arbejdet med ligestilling eller allokering af medarbejderes arbejdstid, således at arbejdet prioriteres. Det kan ligeledes være udbytterigt at allokere ressourcer til ekstern support, som kan rådgive og vejlede medarbejdere og ledere i kommunerne i ligestillingsvurderinger, da det kræver specifikke kompetencer.

Faste procedurer og udvikling af redskaber til brug for ligestillingsarbejdet bidrager til forankring af indsatserne samt gør det nemmere for medarbejdere og ledere at ar- bejde med ligestilling, fordi de har konkrete greb at tage fat i.

Praksiseksemplet nedenfor viser, hvordan ressourcer, procedurer og redskaber kan bidrage positivt til at skabe kvalitet i kerneydelsen.

\section{I forhold til ressourcer, procedurer og redskaber anbefales det:}

- at der afsættes økonomiske midler fra centralt hold til arbejdet med ligestillingsvurdering, og at kommunerne prioriterer arbejdet ved at allokere medarbejdertimer hertil. Dette anbefales koblet med uddannelse i ligestillingsvurdering målrettet de ledere og medarbejdere, der arbejder med kerneydelser, hvor køn er en relevant faktor.

- at der bakkes op om ligestillingsindsatser politisk og ledel- sesmæssigt. Dette bidrager til, at der skabes fokus på, at kønsligestilling fortsat er et område med ulighed.

- at de kommunale interesseorganisationer i de nordiske lande anviser veje og metoder til, hvordan kommunerne kan arbejde med ligestillingsvurdering. Det vil sige, at hidtidige erfaringer kontinuerligt synliggøres. Endvidere bør de tilbyde kommunerne relevant support (sparring og rådgivning) i forhold til ligestillingsarbejdet.

- at der i kommunerne afsættes ressourcer til, at der dels udvikles lokale procedurer for arbejdet med ligestillingsvurdering, dels afsættes ressourcer til at implementere redskaber og metoder, som allerede eksisterer. 


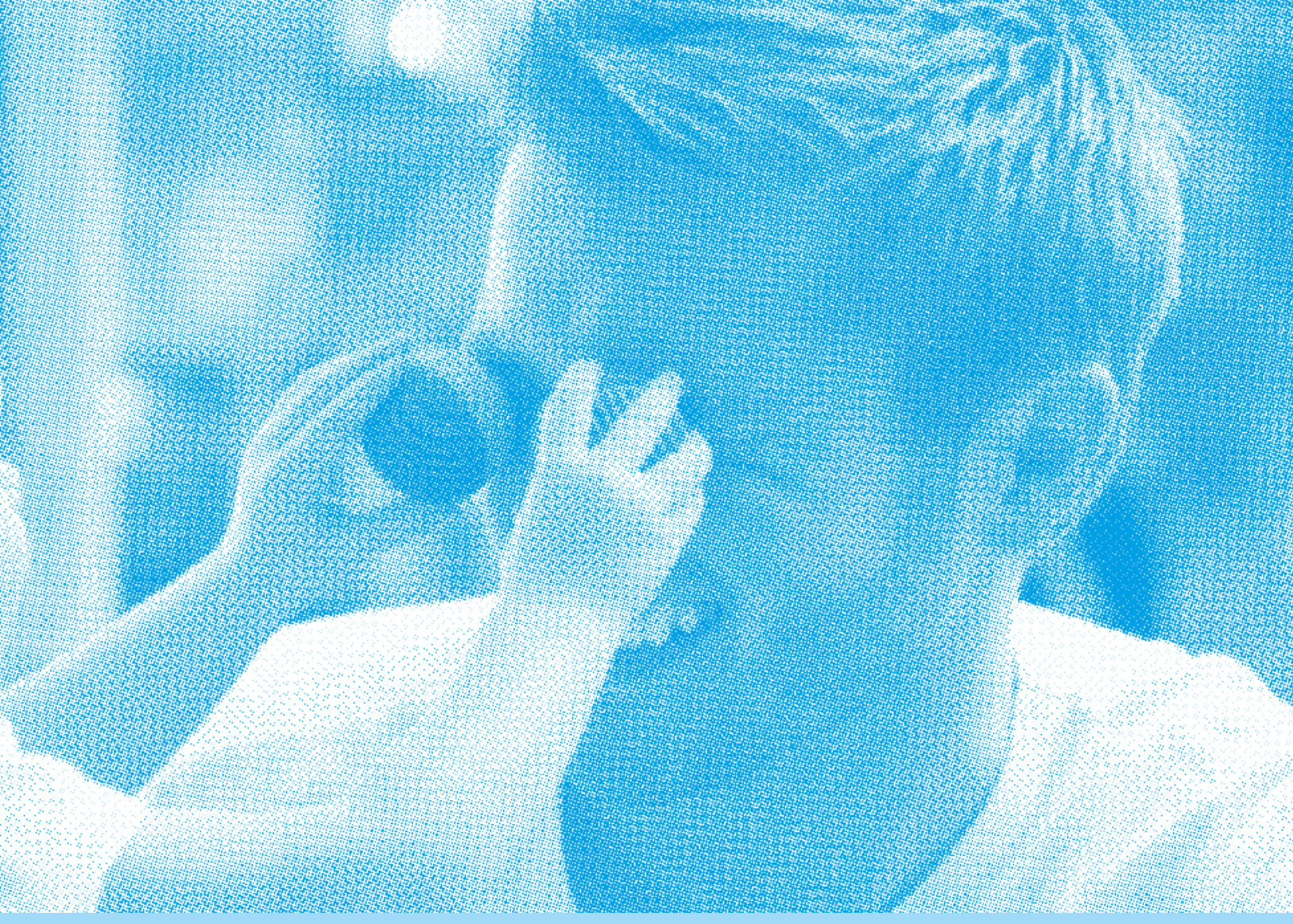

\section{PRAKSISEKSEMPEL - RESSOURCER OG REDSKABER}

Kvinesdal Kommune i Norge arbejder med at øge ligestillingen i kommunens børnehaver samt at videreudvikle de ligestillingstiltag og ligestillingsvurderinger, som allerede er foretaget $\mathrm{i}$ børnehaverne. Et led i programmet er at øge antallet af mandlige ansatte i børnehaverne. Et væsentligt projekt forud for den nuværende indsats var et projekt, hvor pædagoger filmede deres interaktion med børnene, og ud fra optagelserne blev uhensigtsmæssige adfærdsmønstre i børnehaven registreret. Der er udviklet en ligestillingskuffert indeholdende metoder og redskaber til ligestillingsarbejdet i børnehaverne. Kufferten indeholder dels redskaber til at rekruttere mænd til børnehaverne, dels personalerelaterede redskaber samt redskaber til det pædagogiske arbejde med børnene. Disse redskaber har hjulpet børnehaverne til at implementere et mere ligestillet pædagogisk arbejde.

Der er tildelt både eksterne midler og midler fra kommunen til projektet, og det har således været muligt at ansætte en koordinator for projektet svarende til 10-20\% af vedkommendes arbejdstid. Informanterne i denne case vurderer, at det er essentielt for at bevare kontinuitet og undgå, at projektet er båret af ildsjæle, som kan falde fra. 


\subsection{6 \\ DOKUMENTATION}

Dokumentation er en metode

til at synliggøre virkningerne af en indsats. Dokumentation kan påpege, hvilke resultater indsatsen medfører, tilsigtede som utilsigtede. Dokumentation er ligeledes vigtig for en forandringsproces, da dokumentationen kan bidrage til konstant at fastholde fokus på, hvorfor indsatsen gavner og giver mening. Ligeledes kan dokumentation medvirke til at fastholde fokus over tid på ligestillingsområdet. For at kunne dokumentere resultater og effekter på ligestilling er det vigtigt, at der er opstillet konkrete målsætninger og tilkoblet målbare indikatorer i forhold til ligestilling.
Praksiseksemplet nedenfor viser en indsats, hvor der er opstillet målsætninger i forhold til ligestilling, og hvor resultaterne er dokumenteret.

\section{I forhold til brug af dokumentation} anbefales det:

- at der opstilles målsætninger og målbare indikatorer for ligestilling/køn, således at dette sikres $i$ dokumentationen af indsatsens resultater og effekter.

- at der i kommunerne afsættes ressourcer til at dokumentere indsatsernes resultater og ef- fekter i forhold til køn/ligestilling. Påvisning af positive resultater/ effekter i form af $\mathrm{fx}$ øget kvalitet $\mathrm{i}$ kerneydelsen har en kraftig motiverende effekt for at fortsætte ligestillingsarbejdet.

- At der (fortsat) stilles krav om dokumentation i forhold til resultater og effekter for ligestilling ved uddeling af midler til kommunerne. 



\section{YDERLIGERE VIDEN}

For mere viden om kortlægningen og resultaterne heraf og den anvende metode henvises til rapporten Kortlægning af good practice og effekter i de offentlige myndigheders arbejde med ligestillingsvurdering på udvalgte serviceområder - kommunalt niveau. Rapporten er udarbejdet af Oxford Research A/S, september 2014.
Kortlægningen indeholder en analyse af kommunale myndigheders arbejde med ligestillingsvurdering i Danmark, Finland, Norge og Sverige. Analysen er dels baseret på 21 good practice eksempler af nordiske kommuners arbejde med ligestillingsvurderinger af kerneydelser, dels en gennemgang af de politiske, juridiske, økonomiske og kulturelle hovedtræk i de fire nordiske landes (nationale kontekster) arbejde med ligestillingsvurdering.
FINLAND

Oxford Research Oy

Helsinki:

Fredrikinkatu 61a, 6krs.

00100 Helsinki, Suomi

www.oxfordresearch.fi

office@oxfordresearch.fi
BRUXELLES

Oxford Research

C/o ENSR

5. Rue Archiméde Box 4, 1000 Brussels www.oxfordresearch.eu office@oxfordresearch.eu 


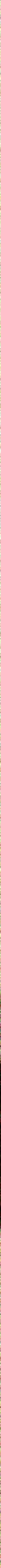


norden

Nordic Council of Ministers

Ved Stranden 18

DK-1061 København K

www.norden.org

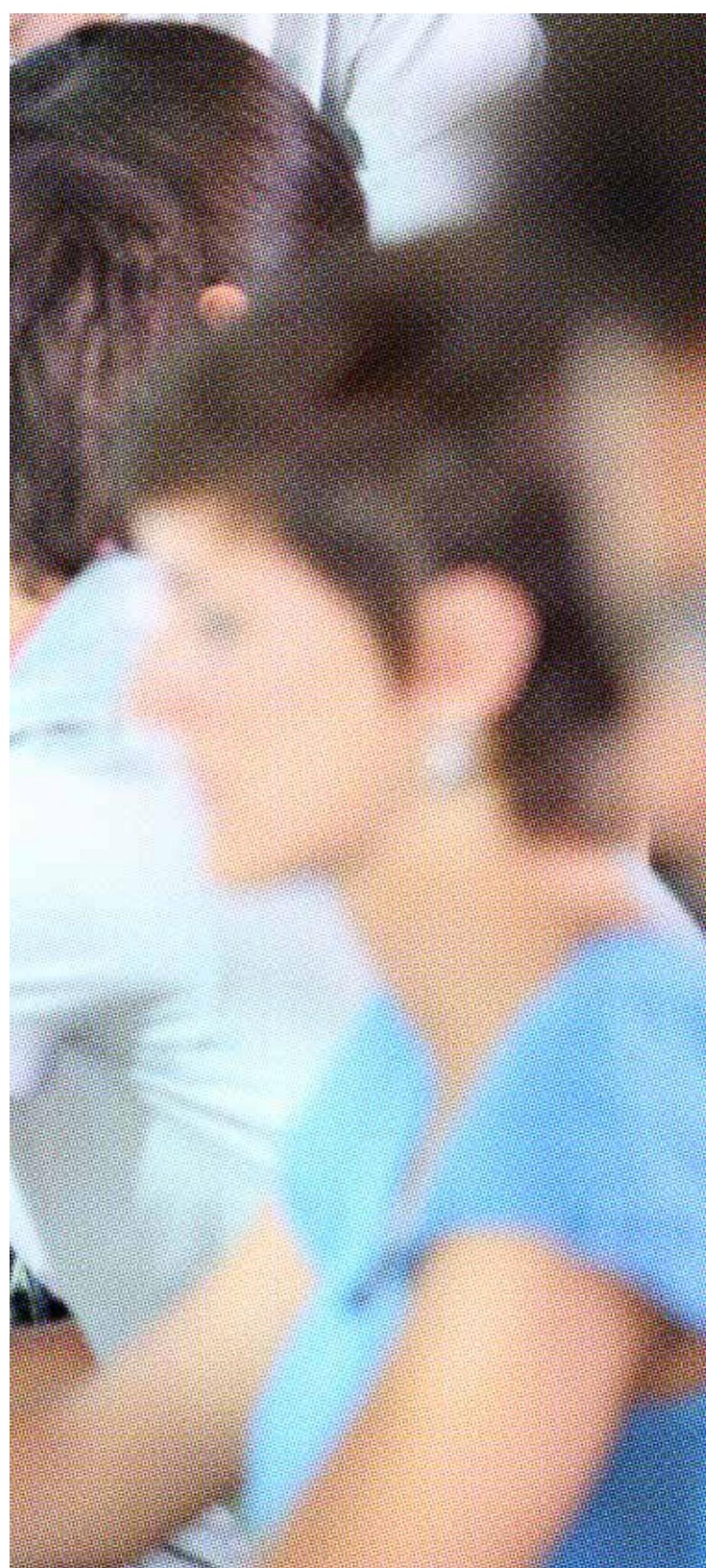

